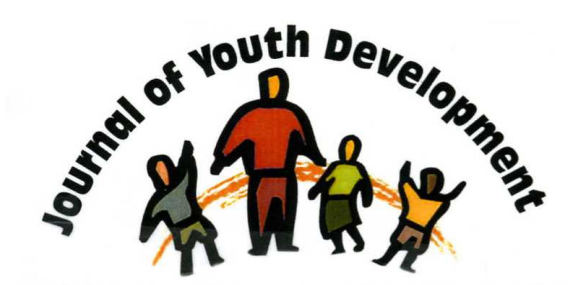

Bridging Research \& Practice

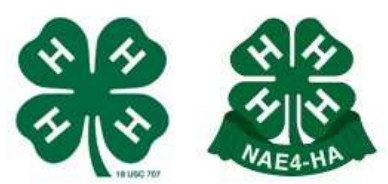

\title{
Differences in the Experiences of Boys and Girls in a Camp Environment
}

\author{
Margaret Miltenberger \\ West Virginia University Extension Service \\ m.miltenberger@mail.wvu.edu
}

Jane Jopling

West Virginia University Extension Service

JEJopling@mail.wvu.edu

Martha S. Garton

West Virginia University Extension Service

MarthaGarton@mail.wvu.edu 


\title{
JOURNAL OF YOUTH DEVELOPMENT \\ bridging research and practice

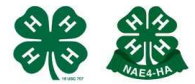

\section{Differences in the Experiences of Boys and Girls in a Camp Environment}

\author{
Margaret Miltenberger, Jane Jopling and Martha S. Garton \\ West Virginia University Extension Service
}

\begin{abstract}
Between the ages of nine and twelve, key developmental differences exist between genders. Boys' and girls' brains simply develop in a different sequence (Sax, 2007) and at a different rate (Hanlon, et al., 1999). Since the 1970's a tendency toward gender blindness and a lack of understanding about the real developmental differences between boys and girls may have limited the ability of youth professionals to best serve all youth. This paper highlights a study of whether boys and girls differ in camp experience and in life skill development as a result of camp? Fifteen counties with 28 individual camps participated in the study which measured (1) camp experience; (2) targeted life skills, and (3) leadership skills. The results showed significant differences between girls and boys. Researchers recommend that gender differences no longer be ignored when programming and that camp activities and curriculum meet the developmental needs of both boys and girls.
\end{abstract}

\section{Background}

Has programming since the mid 1970's been so neutral toward boys and girls that we have been gender blind? Has the goal to be politically correct and offer equal opportunity caused youth professionals to ignore basic differences in boys and girls? Has ignoring the very real underlying developmental differences between boys and girls limited the ability to make desired positive changes in youth development?

Imaging technology is giving scientists new insights into boys' and girls' brain development. This evolving research is showing that girls and boys differ considerably in social, biological and physical development (Armstrong, 2002). The key finding from the past five years in neuroscience brain research is that various regions of the brain develop in a different sequence in girls compared to boys (Sax, 2007). 
An earlier study, the largest and most carefully executed of its type, demonstrated striking and consistent differences in the speed with which the brain matures (Hanlon, Thatcher \& Cline, 1999). The researchers concluded that the areas of the brain for language, spatial memory, motor coordination, and getting along with other people develop in "different order, time, and rate" in girls compared to boys.

One study focused on the rate of processing information. Tyre found that in kindergarten, boys and girls process information at about the same speed. Between ages nine through the twelve the rates of processing information are different. Teenage girls process information faster and middle school boys react to things in a less mature brain location. By 18 , boys and girls were processing with the same speed and accuracy (Tyre, 2005).

Extension and camping programs have not studied in-depth gender differences that may affect best practices. A better understanding of gender differences will give educators another set of tools to support positive youth development. Understanding basic biological and sociological differences will help improve overall camp programs for both genders.

\section{Life Skills Description}

A variety of studies have assessed 4-H program delivery modes using the Targeted Life Skills model. Several have focused on camping: Arnold, Bourdeau, \& Nagele, 2005; Ellerbusch, Callkins, \& Schwarz, 2005; Forsythe Matysik, \& Nelson, 2004; Garst \& Bruce, 2003; and Garton, Miltenberger, \& Pruett, 2007. Among these, only Arnold et al. (2005) discusses at length gender differences discovered in the areas measured.

The Oregon camping study (Arnold, et al., 2005) found statistically significant gender differences in three areas - personal growth, life skill development, and camper satisfaction. Because little has been done to understand gender differences in 4-H programming, the researchers recommend further study.

\section{Camping Program Description}

The camps studied were between four and five days long with campers ranging in age from 914. Camps varied as to program content and theme; however, several basic elements were present: classes, assembly programs, four experiential youth-led learning teams, and an evening campfire program. Campers belonged to the same group year after year and may move up to leadership positions. These teams functioned with a minimum of adult intervention to complete daily camp maintenance responsibilities, participate in team recreation, and prepare for the evening campfire program.

Differences in the experiences of campers based upon gender were unintentional. Males and females were only separated during cottage time at night. Only one of the camps in the study had more male campers than females.

\section{Research Questions}

Do boys and girls differ in life skill and leadership development as a result of camp?

\section{Research Design}

In the summer of 2002, a team of extension agents, in collaboration with researchers at West Virginia University Extension Service, conducted a survey in eight county residential 4-H camps. In 2003 a slightly revised survey was conducted in twenty-eight county residential 4-H camps. 
The results for both studies were very similar. The results reported here focus on younger (ages 8-13) campers' responses to the 2003 study. There were a total of 812 valid surveys (62.34 percent) returned by younger campers.

\section{Instrument}

The survey measured four areas (1) overall camp experience; (2) targeted life skills; (3) leadership skills; and (4) camper demographics. This article focuses on differences between boys' and girls' camp experiences and life skills learned during 4-H camp. The life skills questions selected were drawn from the Iowa Targeting Life Skills Model (Hendricks, 1998 \& Targeting Life Skills, 2008) and related to a camping environment. The validity of the life skill model was demonstrated by Bailey and Deen in 2002.

An age appropriate survey was developed for younger campers (ages 8-13). The instrument was piloted in 2001. The research was conducted with WVU Institutional Review Board (IRB) approval which included parental consent letters for minors and assent letters from youth. The questions were organized around nine life skill categories:

- Learning to Learn

- Decision Making

- Wise Use of Resources

- Responsible Citizenship

- Communication

- Accepting Differences

- Leadership

- Marketable Skills

- Healthy Lifestyles

A Likert Scale was used to measure leadership and team work skills among campers. These skills were:

- Working well with others,

- Working as a member of a team,

- Leading a group or team,

- Taking charge of an activity,

- Knowing how to prepare and lead an activity,

- Sharing leadership with others, and

- Knowing my responsibilities as a leader.

\section{Procedure}

Extension Agents followed outlined procedures for obtaining consent and administering the survey on the last day of each camp. Campers completed the confidential surveys independently. Campers ranked themselves on 10 life skill questions using a four-point Likert scale.

Data was coded and SPSS 10.0 was used for the statistical analysis of the Likert Scale responses to the life skill measures. Frequencies, percentages, central tendency measures, and variability were used to describe the data. One Way ANOVA statistical tests were run to learn if there were gender differences related to camp experience, Life Skills, and leadership skills. 


\section{Research Findings}

\section{Demographics}

Approximately 60 percent of campers were female. Most participants were white/Caucasian; however participants represented a variety of ethnic backgrounds, which were more than representative of the state's minority populations. The relatively high percentage of Native American responses may have been due to youths misunderstanding the ethnic term "Native American."

Table 1

Demographics of Participants - Sex and Ethnicity

\begin{tabular}{|l|c|c|}
\hline \multicolumn{3}{|c|}{ 4-H Camp Participants } \\
\hline Sex & Number & Percent \\
\hline Female & 505 & 62.1 \\
\hline Male & 297 & 36.6 \\
\hline Total & 812 & 100 \\
\hline Ethnicity & & \\
\hline White/Caucasian & 621 & 76.5 \\
\hline Native American & 96 & 11.8 \\
\hline African American & 21 & 2.6 \\
\hline Racially Mixed & 41 & 5.0 \\
\hline Hispanic & 9 & 1.1 \\
\hline Asian American & 7 & .9 \\
\hline Missing & 17 & 2.1 \\
\hline Total & 812 & 100 \\
\hline
\end{tabular}

The majority of campers were between the ages of 9 and 11 years and over 40 percent of participants were attending 4-H camp for the first time. 
Table 2

Demographics of Participants - Age and Years in Camp

\begin{tabular}{|l|c|c|}
\hline \multicolumn{3}{|c|}{2003 4-H Camps for Younger Participants } \\
\hline \multicolumn{1}{|c|}{ Age } & Number & Percent \\
\hline 8 and under & 18 & 2.2 \\
\hline 9 & 143 & 17.6 \\
\hline 10 & 221 & 27.2 \\
\hline 11 & 221 & 27.2 \\
\hline 12 & 139 & 17.2 \\
\hline 13 and older & 53 & 6.5 \\
\hline Missing & 17 & 2.1 \\
\hline Total & 812 & 100 \\
\hline Years in Camp & & \\
\hline First Time & 349 & 43.0 \\
\hline $1-2$ years & 224 & 27.6 \\
\hline $3-4$ years & 185 & 22.8 \\
\hline $5-6$ years & 35 & 4.3 \\
\hline Over 6 years & 5 & .6 \\
\hline Missing & 14 & 1.7 \\
\hline Total & 812 & 100 \\
\hline
\end{tabular}

\section{ANOVA Result Tables}

\section{Differences in Camp Experiences}

There were statistically significant differences between male and female campers. All areas measured had a mean score of 3.62 or higher indicating that both groups had a positive experience. However, in each case, girls had a higher average mean score. Girls had significantly more positive council circle, cabin, and overall camp experiences. There was no statistical difference between groups for camp meals, tribal classes, recreation or assemblies.

Table 3

Comparing Camp Experience (Activity) Items for Boys \& Girls

\begin{tabular}{|l|c|c|r|r|c|}
\hline & Boys & Girls & \multicolumn{1}{c|}{ Df } & \multicolumn{1}{c|}{ F } & \multicolumn{1}{c|}{ Sig. } \\
\hline Camp Meals Experience & 3.87 & 3.85 & 1,762 & .039 & .843 \\
\hline Tribal Classes Experience & 3.87 & 3.80 & 1,733 & .817 & .366 \\
\hline Recreation Experience & 4.05 & 4.03 & 1,751 & .059 & .808 \\
\hline Council Circle Experience & 4.38 & 4.60 & 1,763 & 12.681 &. $\mathbf{0 0 0}$ \\
\hline Cabin Experience & 3.97 & 4.14 & 1,752 & 4.929 &. $\mathbf{0 2 7}$ \\
\hline Assemblies Experience & 3.62 & 3.74 & 1,745 & 2.331 & .127 \\
\hline Overall Camp Experience & 4.38 & 4.59 & 1,743 & 13.347 & $\mathbf{. 0 0 0}$ \\
\hline
\end{tabular}

$\mathrm{p}<.05$. 
Differences in Leadership and Teamwork

There were statistically significant differences between male and female 4-H campers related to leadership and teamwork items. Girls had significantly more positive results on 5 of the 7 areas measured. There were no significant differences related to taking charge of an activity or knowing how to prepare to lead an activity.

Table 4

One Way ANOVA Comparing Leadership and Team Work Items for Boys \& Girls

\begin{tabular}{|l|c|c|c|c|c|}
\hline & Boys & Girls & df & F & Sig. \\
\hline I work well with others. & 3.22 & 3.32 & 1,767 & 4.682 & $\mathbf{. 0 3 1}$ \\
\hline $\begin{array}{l}\text { I am able to work as a member } \\
\text { of a team. }\end{array}$ & 3.43 & 3.54 & 1,763 & 5.134 & $\mathbf{. 0 2 4}$ \\
\hline I can lead a group or team. & 3.04 & 3.21 & 1,753 & 7.401 & $\mathbf{. 0 0 7}$ \\
\hline I can take charge of an activity. & 3.00 & 3.08 & 1,758 & 1.613 & .205 \\
\hline $\begin{array}{l}\text { I know how to prepare to lead an } \\
\text { activity. }\end{array}$ & 3.03 & 3.13 & 1,756 & 2.476 & .116 \\
\hline $\begin{array}{l}\text { I am able to share leadership } \\
\text { with others. }\end{array}$ & 3.33 & 3.49 & 1,753 & 8.939 & $\mathbf{. 0 0 3}$ \\
\hline $\begin{array}{l}\text { I know what my responsibilities } \\
\text { as a leader are. }\end{array}$ & 3.30 & 3.43 & 1,761 & 4.662 & $\mathbf{. 0 3 1}$ \\
\hline
\end{tabular}

$\mathrm{p}<.05$.

\section{Differences in Life Skills}

There were statistically significant differences between girls and boys in certain Life Skill measures. On the Life Skill measures girls had significantly more positive gains in areas that required more social/emotional skills:

- respecting other campers,

- considering how my actions affect others,

- listening carefully to what others say,

- accepting ideas different than mind,

- making friends with people different than myself, and

- participating as a member of a team.

There was no statistical difference between girls and boys when the Life Skill area was a specific learning topic.

- learning to be more interested in learning,

- learning ways to improve the earth,

- learning to live a healthy lifestyle, and

- learning to never use drugs or alcohol. 
Table 5

One Way ANOVA Comparing Life Skills Learned by Boys with Life Skills Learned by Girls

\begin{tabular}{|l|c|r|r|r|c|}
\hline & $\begin{array}{c}\text { Mean } \\
\text { Boys }\end{array}$ & Mean Girls & df & F & Sig. \\
\hline $\begin{array}{l}\text { During 4-H Camp I have learned ... To be } \\
\text { more interested in learning. }\end{array}$ & 2.32 & 2.31 & 1 & .008 & .927 \\
\hline $\begin{array}{l}\text { During 4-H Camp I have learned ... Ways } \\
\text { I can help improve the earth. }\end{array}$ & 2.42 & 2.39 & 1 & .505 & .477 \\
\hline $\begin{array}{l}\text { During 4-H Camp I have learned ... To } \\
\text { respect the other campers. }\end{array}$ & 2.73 & 2.87 & 1 & 18.331 &. $\mathbf{0 0 0}$ \\
\hline $\begin{array}{l}\text { During 4-H Camp I have learned ... To } \\
\text { consider how my actions affect others. }\end{array}$ & 2.47 & 2.65 & 1 & 15.886 & $\mathbf{. 0 0 0}$ \\
\hline $\begin{array}{l}\text { During 4-H Camp I have learned ... To } \\
\text { listen carefully to what others say. }\end{array}$ & 2.62 & 2.80 & 1 & 21.441 & $\mathbf{. 0 0 0}$ \\
\hline $\begin{array}{l}\text { During 4-H Camp I have learned ... To } \\
\text { accept ideas different than mine. }\end{array}$ & 2.59 & 2.74 & 1 & 12.573 & $\mathbf{. 0 0 0}$ \\
\hline $\begin{array}{l}\text { During 4-H Camp I have learned ... To } \\
\text { make friends with people different than } \\
\text { myself. }\end{array}$ & 2.75 & 2.86 & 1 & 11.482 & $\mathbf{. 0 0 1}$ \\
\hline $\begin{array}{l}\text { During 4-H Camp I have learned ... To } \\
\text { participate as a member of a team. }\end{array}$ & 2.71 & 2.83 & 1 & 10.941 & $\mathbf{. 0 0 1}$ \\
\hline $\begin{array}{l}\text { During 4-H Camp I have learned ... To } \\
\text { live a healthy lifestyle. }\end{array}$ & 2.56 & 2.64 & 1 & 3.198 & .074 \\
\hline $\begin{array}{l}\text { During 4-H Camp I have learned ... To } \\
\text { never use illegal drugs or alcohol. }\end{array}$ & 2.63 & 2.69 & 1 & 1.698 & .193 \\
\hline
\end{tabular}

$\mathrm{p}<.05$.

\section{Limitations and Critique of the Assessment}

All of the camps except one in this study had 60 percent or more girls in camp than boys. Although there were no intentional differences in camp programming, the fact remains that a larger number of girls attended the camping programs. The camping program (and perhaps the entire 4-H program) may be more attractive to girls than boys. Even if the program initially appeals equally to boys and girls, the very fact that more girls are present could cause boys to be reluctant to participate with equal enthusiasm, reducing their enjoyment and their life skill gains.

The reliance on self-reporting to measure change may not be the most accurate method of gathering reliable information. The evaluations were conducted during the last day of $4-\mathrm{H}$ camp. Youth are usually feeling great about camp at this time, so they may over-estimate skills learned. 
Another limitation of this study is pointed out by Stossell (2007) in an article for ABC News. Girls are much more likely to be polite and boys are more likely to be honest. There is some possibility that the girls who were surveyed gave the items a higher rating than the boys who were surveyed.

\section{Conclusions}

Camp experiences. Significant gender differences were found in the basic camp experience. Girls had a significantly more positive experience among three of the seven areas measured. In comparison, the Oregon camp study (Arnold, et al, 2005) also found significant gender differences among four of the five items measured related to camper satisfaction.

Leadership and teamwork skills. Girls had significantly more positive results on five of the seven areas measured relating to leadership and teamwork. Stafford, Boyd \& Lindner (2003) also found significantly more positive results on leadership skills among girls. T-tests revealed that gender had a significant influence on the "effective team skills" subscale group of questions. Females perceived themselves as possessing more effective team skills than males $(t=-2.31)$ on one subset. Both studies indicated that boys and girls are comfortable taking on a leadership role.

Life skills. Research over time has shown that the language skills of most girls develop earlier than boys. Girls also have emotion processed with that language development (Sax, 2007). Given that many of the life skills identified by Hendricks (1998) are relational in nature it makes sense that there may be significant differences in development between boys and on some of the life skill items (Arnold, et al., 2005). In this study, girls had significantly more positive gains in the life skill measures that required more social/emotional skills.

- I work well with others.

- I am able to work as a member of a team.

- I can lead a group or team.

- I am able to share leadership with others.

- I know what my responsibilities as a leader are.

Arnold, et al. (2005) also found statistically significant differences using one-way analysis of variance (ANOVA) between boys' and girls' reported life skill development as a result of camp on three of the eight measures. Although difficult to make a direct comparison, this study did show a mix of significant results related to social emotional skills.

\section{Discussion}

1. Gender differences should no longer be ignored when programming. The practice of gender blindness must be replaced by efforts to understand gender differences and ways to avoid stereotyping youth. (Sax, 2007). Youth educators must continue to measure the relative numbers of boys and girls involved and use the most current gender research for optimum program opportunities. Tyre says, in her 2006 Newsweek article, "Boys measure everything they do or say by a single yardstick: does this make me look weak? And if it does, I am not going to do it!" If this is true, then we must provide boys with the means to calibrate how hard the social and emotional challenges at camp are going to be and help them determine that they can succeed. 
2. Camping activities and curriculum should meet the developmental needs of both genders. To do a better job of teaching life skills to boys such as citizenship, communication and accepting differences, educators must develop activities which cater to their different developmental needs.

3. The camping environment provides the large space boys particularly need to allow for plenty of physical activity. Camp has a marvelous advantage over the traditional school system which emphasizes sitting quietly and expressing thoughts and feelings through language. The mismatch between boy behaviors and classroom expectations is often obvious. Camp is typically more active and faster paced. These attributes cater to the information about the differences in the male brain (Armstrong, 2002) and support a positive learning experience for boys.

4. Activities which enhance relationships and social interaction should be intentionally planned (Huston, Carpenter, Atwater, \& Johnson, 1986). Boys prefer interactions in large groups as opposed to triads and dyads which girls prefer (Gurian, 1996). Educators need to learn how to take advantage of these differences, and provide programs which intrigue and involve both genders.

5. Camp activities must offer adventure and a sense of mission. Gurian's The Wonder of Boys advises: "When we work with boys, we do them and ourselves a great service by opening up to them an equal measure of adventure and mission. Their individual lives must become an adventure in which they discover and experience who they are and in that discovery get 'hooked up' with their own power."

6. Activities should allow for healthy competition and a chance for youth to perform well. Competition is a form of nurturing behavior for boys. Gurian maintains that "A boy who is not being taught skills, shown to compete successfully, and given praise for his success, feels lost. Boys compete verbally and physically and base some relationships on competition. They have formed cultural and linguistic constructs in which to gain selfimage through this strategy." (Gurian, 1996). Sports are an important part of most camping programs. When a boy hears, "Be on our team, you're one of us," he feels he has a place to belong. Large group sports allow boys to express male aggressiveness with structure, skill and focus. Too often in community and school sports, parents and coaches don't seem to perceive what kids are experiencing and what they really need (Wiersma \& Sherman, 2005). Adults often misunderstand the important role that the sports program has in developing self esteem, teamwork, and respect for authority. In order to maximize the power of the camping sports programs, counselors must be trained to provide skill training, compassion and the positive role models that are needed for youth to benefit from sports programs at camp.

7. It is important that trained counselors serving as role models understand and respect the gender differences and can interact effectively with both boys and girls. Tyre (2006) reports that one of the most reliable predicators of whether a boy will succeed or fail in high school rests on a single question: Does he have a man in his life to look up to? A comparison of gender differences among volunteers, agents, and specialists (Culp, McKee, \& Nestor, 2005) indicated that the total percentage of females serving the 4-H program outnumbered the percentage of males by four to one. An implication of this study is the need to recruit and train counselors to provide the kinds of role models necessary to maximize the power of the camping situation for both boys and girls. 


\section{Recommendations}

This study and a growing body of research and literature about the differences between boys and girls point toward a need to increase the knowledge about gender differences among youth development professionals. Researchers recommend that youth development professionals:

- consider gender differences when developing programs;

- plan camp activities and use curriculum that meets the developmental needs of both genders;

- take advantage of the camping environment which provides the large space boys particularly need to allow for plenty of physical activity;

- intentionally include activities which enhance relationships and social interaction;

- use experiential learning to create a sense of adventure in camping programs;

- plan activities which allow healthy competition and a chance for youth to perform well; and,

- recruit, screen and train counselors to serve as role models who respect gender differences and interact effectively with both boys and girls.

\section{Recommendations for Research}

Further research is needed to determine what attracts boys to certain activities and what attracts girls. Focus groups might help better understand camp experiences and youth organizations in relation to gender. For instance, is it true that boys choose activities that will make them appear strong and "male"? How can we market camp and youth activities to appeal to boys as well as girls? How can we enhance the cabin experience of boys? Do more hazing activities happen in the boys' cabins and with organizations that cater primarily to boys? How can we train male cabin counselors, coaches, and adult volunteers so that strong positive relationships are formed?

Even now, according the National Center for Education Statistics (2004) the college going rate is skewed about 57/43 toward women. Research is needed to clarify what draws each gender to organizations and what elements will maximize leadership and skill development for all youth with regard to gender. Youth development organizations concerned with increasing college going rates must look carefully at how they are relating to both boys and girls and discover ways to enhance effectiveness across genders.

\section{References}

Armstrong, K. (2002). Parenting to the difference in boys and girls. Fargo, ND: University of North Dakota Extension. Retrieved March 13, 2008 from http://www.ext.nodak.edu/county/rolette/parentingthediff.html

Arnold, M.E., Bourdeau, V.D., \& Nagele, J. (2005). Fun and friendship in the natural world: the impact of Oregon 4-H residential camping programs on girl and boy campers. Journal of Extension [On-line], 43(6), Article 6RIB1. Retrieved from: http://www.joe.org/joe/2005december/rbl.shtml 
Bailey, S., \& Deen, M. (2002). Development of a web-based evaluation system: a tool for measuring life skills in youth and family programs. Family Relations, 51:138-147.

Culp, K., III, McKee R.K., \& Nestor, P. (2005). Demographic differences of 4-H volunteers, agents, and state volunteerism specialists: implications for volunteer administration. Journal of Extension [On-line], 43(4), Article 4FEA2 Available at:

http://www.joe.org/joe/2005august/a2.shtml

Ellerbusch, K., Calkins, C., \& Schwarz, J. (2005). An evaluation of the effectiveness of life skill development in Missouri's 4-H youth resident summer camps. University of Missouri Extension.

Forsythe, K., Matysik, R., \& Nelson, K. (2004). Impact of the 4-H camp counseling experience. Research Paper. Madison, WI: University of Wisconsin Extension Department of Youth Development.

Garst, B.A., \& Bruce, F.A. (2003). Identifying 4-H camping outcomes using a standardized evaluation process across multiple 4-H educational centers. Journal of Extension [On-line], 41(3). Available at: http://www.joe.org/joe/2003june/rb2.shtml

Garton, M.S., Miltenberger, M., \& Pruett, B. (2007). Does 4-H camp influence life skill and leadership development? Journal of Extension [On-line], 45(4). Available at:

http://www.jor.org/joe/2007august/a4.shtml

Gurian, M. (1996). The Wonder of Boys. New York, New York: Penguin Putnam Books.

Hanlon, H., Thatcher, R., \& Cline, M. (1999). Gender differences in the development of EEG coherence in normal children. Developmental Neuropsychology, 16(3): 479-506.

Hendricks, P. (1998, Revised 2006). Developing Youth Curriculum Using the Targeting Life Skills Model: Incorporating Developmentally Appropriate Learning Opportunities to Assess Impact of Life Skill Development, Ames, IA: Iowa State University Extension. Available at https://www.extension.iastate.edu/store/ListItems.aspx?Keyword=4H137.

Huston, A.C., Carpenter, C.J., Atwater, J.B., \& Johnson, L.M. (1986). Gender, adult structuring of activities and social behavior in middle childhood. Child Development, 57(5): 1200-1209.

National Center for Education Statistics. (2004). Enrollment in postsecondary institutions. United States Department of Education. Retrieved March 14, 2008 from

http://search.nces.ed.gov/search?output $=x m l$ no $d t d \& s i t e=$ nces\&client=nces\&proxystylesheet =nces\&q=college+enrollment

Sax, L. (2007). Why gender matters presentation. Deerfield, MA: Deerfield Academy. Retrieved February 26, 2008 from: http://deerfield.edu/parents/index.cfm?page ID=279

Stafford, J., Boyd, B., \& Lindner, J.R. (2003). Community service versus service-learning: which is best for 4-H? Journal of Extension [On-line], 41(6). Retrieved from:

http://www.joe.org/joe/2003december/a1.shtml

Stossell, J. (2007). Differences between boys and girls. ABC News. Retrieved March 14, 2008 from: http://www.abcnews.go.com/print?id=123726 
Targeting life skills model. Ames, IA: Iowa State University Extension. Retrieved December 5, 2008, from http://www.extension.iastate.edu/4H/lifeskills/.

Tyre, P. (2005). Boy's brains, girl's brains: are separate classrooms the best way to teach kids? Newsweek. September, 2005:59.

Tyre, P. (2006). Boy crisis: the trouble with boys. Newsweek, January 2006: 44-53.

Wiersma, L.D. \& Sherman C.P. (2005). Volunteer youth sport coaches' perspectives of coaching, education/certification and parental codes of conduct. Research Quarterly for Exercise and Sport. 76(3): 324-338.

(C) Copyright of Journal of Youth Development Bridging Research and Practice. Content may not be copied or emailed to multiple sites or posted to a listserv without copyright holder's express written permission. However, users may print, download or email articles for individual use. 